\title{
EL NADAÍSMO Y "LA VIOLENCIA" EN COLOMBIA
}

\author{
POR \\ Juan Carlos Galeano \\ Utica College of Syracuse University
}

\begin{abstract}
No, señor Padilla, no somos un producto inglés ni francés: somos el producto típico de un cambio de "ritmo" histórico y violento que desquició las estructuras de la sociedad y los valores espirituales del hombre colombiano. Converse usted - si no teme perder media hora de su preciosa inmortalidad — conjóvenes nadástas de mi generación que oscilan entre los 20 y los treinta años, como Pablus Gallinazo, J. Mario, o William Agudelo, y ellos le dirán horrores de lo que vivieron y padecieron en sus aldeas de Santander, Antioquia y el Valle del Cauca. Le contarán, señor, cómo eran de siniestros los tiroteos de la chusma, y cómo sonaba de insensible y terrorifica la sirena del verdugo. Usted no se imagina cómo, porque en sus tiempos pre-natales todo era muy idílico y no había peligro de que el futuro ciudadano fuera arrojado del nido con los traumas que hoy arrastra mi generación. ${ }^{1}$
\end{abstract}

Así declaraba airado Gonzalo Arango una de las razones del origen del movimiento nadaísta. La rabia y la desesperanza con que dejó "la violencia" a su generación se manifiesta con valor documental en sus palabras. No fue posible para la mayoría de los poetas nadaístas evadir la vivencia de los desastres; al pertenecer sus familias a la clase popular, el genocidio los sorprendió en plena niñez a unos y en la adolescencia a otros.

Desde fines de los años 40 hasta mediados de los 60 la guerra fratricida fue el mal viento que sacudió el árbol de la vida de los colombianos; tras esos años de crímenes atroces y alevosía ni el país ni el arte volvieron a ser los mismos. "La violencia" que fue expuesta por prosistas, dramaturgos, pintores y guionistas, fue reflejada asimismo, en su inmediatez, por la poesía. Fueron pocos los poetas colombianos que se mantuvieron ajenos a la tragedia que embargó al país con más de 200.000 muertes, y una poesía de "la violencia" se originó en dos vertientes: primero, un gran "corpus" poético de tono consolatorio y optimista que

\footnotetext{
${ }^{1}$ Juan Gustavo Cobo Borda, "El nadaísmo 1958-1963," Eco 224-226 (1980) 356. Ésta es una de las declaraciones del "profeta" Gonzalo Arango, recogidas por Cobo Borda.
} 
contiene la poesía de los vates populares y de los poetas de la generación de la revista Mito; en esta poesía se destacan motivos temáticos como la fecundación de la tierra por las víctimas, el elogio de los héroes y la paz quebrantada. ${ }^{2}$ Segundo, lo que es objeto de nuestro estudio: una breve vertiente de poesía pesimista que inscribe el puñado de poemas sobre "la violencia" de Gonzalo Arango, Jaime Jaramillo Escobar, Jota Mario Arbeláez y Armando Romero. Dichos textos forman parte de su posición de rechazo general a la sociedad colombiana. ${ }^{3}$

Antes de considerar sus poemas sobre "la violencia" y para facilitar su ubicación, se hace necesario mencionar el lugar de los nadaístas en la poesía colombiana de la época, pues este movimiento no fue una prolongación de ninguna de las tendencias poéticas precedentes. Con relación a Mito, el grupo anterior, se hallaban aislados, ya que los poetas de la revista se habían formado literariamente bajo algunas influencias de la poesía colombiana precedente, así como por un clima universal aureolado por el existencialismo y la crítica intelectualmente sistemática. Los nadaístas, al no recibir legado alguno de la poesía nacional, van a crecer, entonces, apartados de los movimientos literarios colombianos, aunque no menospreciados por ellos. Los nadaístas si hubieran podido ser herederos de alguien lo habrían sido de Catulo, de los juglares satíricos de la Edad Media, o de Valle-Inclán por sus espejos cóncavos y visión antiheroica. Tendrán que inventarse en medio del caos sus modelos estéticos y hallar sus propios maestros literarios; el más notorio de ellos fue Fernando González, un filósofo nihilista vernáculo, quien vivía apartado de las capillas literarias de ese tiempo. Sin embargo, una actitud de apertura de algunos miembros de Mito, especialmente aquélla del poeta Jorge Gaitán Durán, facilitó un poco el camino hacia la difusión del movimiento nadaísta. La dedicación del último número de la revista evidencia el espaldarazo de aprobación tácita.

El nadaísmo surgirá durante los últimos años de "la violencia." En Medellín, en 1958, aparece el Manifiesto nadaísta (folleto firmado por GonzaloArango [sic] que presentaba su proyecto de revolución humana, respaldando su posición con citas de autores como

\footnotetext{
${ }^{2}$ Dicha poesía se caracteriza por un exceso de imágenes propagandísticas en las que la grandilocuencia, "los slogans" y las manifestaciones del odio hacia el enemigo son lugares comunes. Los poetas (especialmente aquéllos no pertenecientes a Mito), no sólo pecan de panfletarios, sino que, algunos, acusan un mal uso de la tradición poética sobre la cual edifican sus poemas. El autor de este artículo estudia extensamente esta poesía de "la violencia" en Colombia en $A$ gricultura de la muerte, libro en vías de publicación.

${ }^{3}$ La información general sobre el nadaísmo ha sido obtenido de los siguientes autores: Helena Araujo, Signos y mensajes (Bogotá: Instituto Colombiano de Cultura, 1976); Juan Gustavo Cobo Borda, Poesia colombiana 1890-1980 (Medellín, Colombia: Editorial Universidad de Antioquia, 1987); y "El nadaísmo 1958-1963," Eco 224-226 (1980) 348-370; Eduardo Escobar, Gonzalo Arango (Bogotá: Procultura S.A., 1989); Darío Jaramillo Agudelo, "La poesfa nadaísta," Revista Iberoamericana 128-129(1984) 758-798; Samuel Jaramillo, "Cinco tendencias de lapoesía postnadaísta en Colombia," Eco 224-226 (1980) 371-393; Armando Romero, El nadaismo colombiano, o la búsqueda de una vanguardia perdida (Bogotá: Tercer Mundo Editores, 1988), entrevista a este mismo autor concedida el 1 de julio de 1992, en Cincinnati, Ohio, Estados Unidos, y Gente de pluma (Madrid: Editorial Orígenes, 1989). Las referencias a los anteriores textos y autores serán dadas mediante el apellido del autor, y, cuando se trata de más de una obra del mismo autor, el título abreviado del libro con su respectivo número de página.
} 
Mallarmé, Sartre, Bretón, Kafka, Gide, entre otros.) La premisa fundamental para su programa de cambios a la sociedad conllevaba la negación frontal y la irreverencia hacia todos los valores estéticos, sociales y religiosos del país. El nadaísta Gonzalo Arango en su tarea de agente fundador y promotor del desequilibrio auguraba:

La lucha será desigual considerando el poder concentrado de que disponen nuestros enemigos: la economia del país, las universidades, la religión, la prensa y demás vehículos de expresión del pensamiento (...) La aspiración fundamental del nadaísmo es desacreditar ese orden.

(Cobo Borda 184)

La tarea de desacralización del orden establecido habría de llevarse a cabo a través de dos vehículos: el literario y el de la acción. El primero fue la revista $\mathrm{Nada}$, anunciado órgano del movimiento que solamente apareció a principios de los años setenta con la publicación de Nadaismo 70, con ocho números; y el segundo, por medio de la actitud desafiante de los adeptos al movimiento (Cobo 184). Ellos eran jóvenes, hijos de la clase media baja tirados a la orilla de la desilusión por la resaca de "la violencia." Se negaban a "dar vuelta a la noria" y querían construir una modernidad que los salvara de la mediocre vida de trabajos forzados; eran los desertores de los pequeños empleos, de los bancos, de los colegios, universidades y seminarios. Preferían abrazar su nueva religión: "la literatura como un ocio," como lo afirmaba Jota Mario, y una vida errante en los bares y cafés como El Metropol, La Bastilla, La Clínica Soma; una peregrinación a la que agregaban su búsqueda del amor libre, el consumo de marihuana y LSD. (Romero, El nadaismo colombiano 38-39, 64-65)

Dentro de ese plano de acción, de promover y hacer notorio el movimiento por todo el país, llevaron a cabo giras por Manizales, Pereira, Cali (1960) y Bogotá (1961). En Cali llegaron a pedir la sustitución del busto de Isaacs, el respetable autor de Maria, por el de Brigitte Bardot. En esta misma ciudad se unieron los caleños J. Mario y Elmo Valencia, agrupándose también junto a Gonzalo Arango, los poetas Jaime Jaramillo Escobar (alias X504), Eduardo Escobar, Alberto Escobar, Darío Lemos, el novelista Humberto Navarro, los cuentistas Amilcar Osorio y Jaime Espinel. En 1963, la antología 13 poetas nadaistas agrupaba a los poetas y cuentistas mencionados anteriormente y a Mario Rivero. Pocos años más tarde la publicación De la nada al nadaísmo (1966) presentaba a Armando Romero, Elkin Restrepo, Fanny Buitrago y David Bonells. (Cobo 189)

En cuanto a la literatura dejada por el movimiento hay textos de extremismo a ultranza, de protesta contra una sociedad mojigata, reflejo de la violencia que traen quienes han sido arrancados de su ancestro campesino y mudados a los ambientes citadinos donde la técnica y el horario dominan. Este nuevo paisaje, sumado a su pasión juvenil, quizás hace que ellos quieran dejar de lado la camisa de fuerza de la lírica tradicional y prefieran la respiración amplia del verso largo. Mas es un ritmo alterado por el ruido de la ciudad. En esta escritura se dan las frases tortuosas, los cambios en la sintaxis, las sorpresas a la entrada y salida de cada verso. Sobre dichos significantes se monta el histrionismo que les valió la burla y admiración de los críticos y demás escritores colombianos. Parece que en su poesía una nota predominante la constituye el humor negro, un aspecto que, como demostraremos, provee el antídoto o su exordio contra la muerte que los rodeaba (Araújo 189; Darío Jaramillo 758). Si la poesía del grupo de Mito constituyó la crítica tácita al acartonamiento que había padecido la poesía colombiana hasta la década de los cincuenta, con la obra poética general 
de los nadaístas se afirma el golpe de gracia a tal lírica de la primera mitad de siglo. Los nadaístas abandonan los altares del romanticismo lacrimoso y los paisajes etéreos para hacerse más de este mundo. Sus versos roídos por la ironía, los paisajes del barrio y la ciudad presagian los textos bañados por la cotidianidad, la crítica, la política y el erotismo de la poesía colombiana contemporánea de poetas como Juan Manuel Roca, Darío Jaramillo Agudelo, María Mercedes Carranza y Juan Gustavo Cobo Borda. Es indudable que la poesía colombiana de hoy le adeuda una parte a los nadaístas por su propuesta del pensamiento y del lenguaje poéticos. Sería imposible aquí, por virtud de espacio, hacer un balance sobre toda la profusa actividad literaría de los nadaístas consignada en casi todos los géneros literarios. Pasada la época de la acción y de los textos incendiarios ha quedado una cantidad no desdeñable de poemas decantados del ripio.

En este mismo contexto de creación literaria general de los nadaístas se hallan algunos pocos poemas que ponen su dedo acusatorio en la llaga. ${ }^{4}$ Tales textos que en mucho comportan el carácter de crónica sobre "la violencia," debido a su naturaleza referencial, también contienen una suerte de conjuro de la misma. Desencantados de la patria, sus valores y sus líderes, la única opción que les queda a los nadaístas es la burla amargada. Ello provoca que la mayoria de sus poemas de "la violencia" comporten, especialmente en los textos de Gonzalo Arango y Jaime Jaramillo Escobar, un exorcismo montado sobre la ironía. Su humor negro como aquél de otros lugares y épocas "se incrementa en épocas de crisis cuando el ser humano experimenta su impotencia como individuo contra las fuerzas contra las cuales él tiene muy poco o ningún control."5

\section{GonzALo Arango}

Este poeta (1931-1976) viene a la ciudad de Medellín siguiendo las migraciones campesinas provocadas por "la violencia" de los campos y aldeas hacia los centros urbanos. La catástrofe nacional trae un desequilibrio que marca su vida. Una referencia de Arango al asesinato de Jorge Eliécer Gaitán, el líder liberal, documenta tal incidencia:

9 de abril: la misteriosa madeja del destino. La muerte de este hombre altera mi vida. (...) Esa tarde, la Revolución se resbaló y cayó en el infierno de la violencia. (...) mi padre nos encerró en un cuarto oscuro y nos rezó como siempre que había tormenta: 'Aplaca Señor tu ira, tu justicia y tu rigor'. (...) Para mí esas oraciones eran el fin del mundo, el diluvio y la guerra. Yo rezaba y lloraba al mismo tiempo. ${ }^{6}$

Sus palabras también son paradigma de una cierta determinación de destinos que le impone la historia:

\footnotetext{
${ }^{4}$ Este aspecto de los poetas miembros del movimiento nadaísta "ofreciendo su más relevante manifestación acusatoria ...," ha sido mencionado tangencialmente por Alvaro Quiroga Cifuentes en "Evolución, objeto y universalidad en la literatura de la violencia en Colombia," en II Simposio Nacional sobre la Violencia en Colombia ed. (Bogotá: Editora Guadalupe Ltda., 1988) 206.

${ }^{5}$ Linda Horvay Barnes, The Dialectics of Black Humor: Process and Product (Berne, Switzerland: Peter Lang Ltd., 1978) 90. La traducción es mía.

${ }^{6}$ Gonzalo Arango, Obra negra (Buenos Aires: Ediciones Carlos Lohlé, 1974) 59.
} 
Si Gaitán no hubiera muerto, yo no sería hoy Gonzalo Arango ¿Quién o qué sería? No lo sé. No juego a la nostalgia ni a la profecía. Pero sí tengo la certeza de que si Gaitán viviera, el nadaísmo nunca habría existido en Colombia. Entonces, ¿dónde estaríamos y qué estaríamos haciendo los escritores nuevos? Es casi seguro que hoy estaríamos al lado de Gaitán, con Gaitán a la carga, defendiendo sus banderas revolucionarias.

(Arango 59)

Después de la muerte de Gaitán, al que siguen los años de afiebradas lecturas y desvarío político, ${ }^{7}$ Gonzalo Arango lanza su Manifiesto nadaista en 1958, llamando la atención de varios jóvenes que, como él, habían perdido la confianza en los valores patrios, instituciones, $\mathrm{y}$, sobre todo, en los partidos políticos. Estaba en su camino de fundador del movimiento nadaísta y de un destino rebelde.

Tocada su vida entonces por la guerra civil no declarada entre los hermanos de su misma tierra, Gonzalo Arango habría de presentar su compromiso en diversos lugares de su vida. No sólo con sus declaraciones directas sobre la forma en que se vio afectado por ésta, sino también en poemas de protesta expresa. Su "Poema revolucionario" se constituye como una suerte de crónica sobre la historia del país; en su hastío ve el absurdo brutal del derrumbe de la patria y sus falsos ídolos:

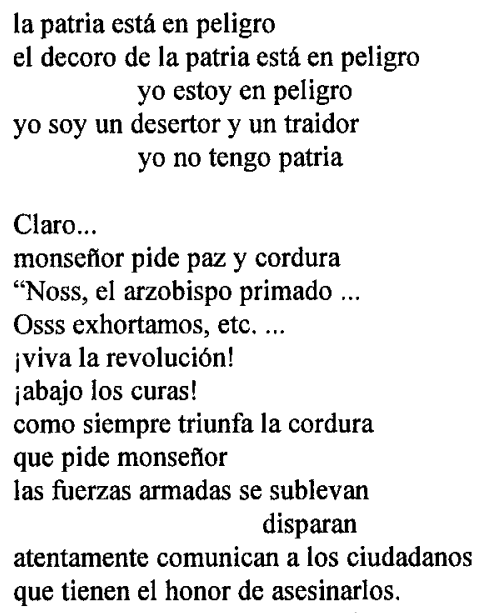

(Romero, El nadaismo colombiano 105-106)

Es claro que el poeta ofrece su noción en la vena del sarcasmo sobre la actitud de la iglesia frente a "la violencia," pues bien se sabe que muchos miembros del clero, al tiempo que instigaban a los miembros del partido conservador a arremeter contra los liberales

\footnotetext{
${ }^{7}$ Valga anotar que Arango, en las muchas vueltas de su desordenada itinerancia, por un tiempo se adhirí al MAN, una fuerza política fundada por el dictador Gustavo Rojas Pinilla. Permaneció allí hasta 1957, año en que el general es derrocado por el pacto de los partidos liberal y conservador $(E l$ nadaísmo colombiano 35).
} 
"enemigos de Dios," pedían cordura a los aterrorizados miembros civiles liberales, quienes en las poblaciones y veredas querían oponer resistencia a la policíay al ejército. ${ }^{8}$ Así mismo, nos ofrece su crónica sobre lo que pasa en su "patria;" y la burla, el humor negro y la rabia son el soporte de su poema. El carnaval iconoclasta de sus versos parodia el eterno discurso de "las frases de cajón" de los políticos y salta a lo abrupto del discurso moderno de los medios masivos de comunicación que señalan el paso de un país campesino a la irrisoria modernidad del consumo:

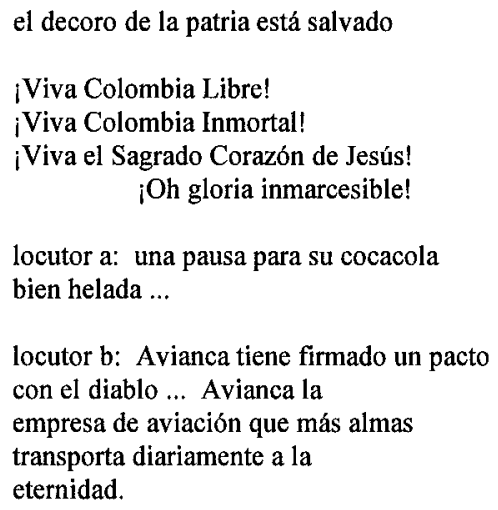

(Romero, El nadaismo colombiano 107)

La alusión en el poema a los nuevos productos de la comercialización y de la sociedad de consumo que cobraban fuerza en los años de "la violencia," corresponde a la realidad. Sin embargo, la verdad que se evidencia en la horda de campesinos desterrados por los desastres e incorporados a la vida citadina a consumir la radio y la Cocacola, también contiene su negación, y ésta la expone el poeta con una gran ironía. Si hay una celebración de lo nuevo, también existe una negación de lo mismo porque su alusión contiene la crítica. La exaltación de lo nuevo está socavada por su negación: la burla. La compañía aérea que los profetas de la economía nacional y los políticos seguramente le presentan con orgullo a las masas analfabetas colombianas es blanco del humor corrosivo del poeta. A diferencia del futurismo, cuyo teórico principal Marinetti, desde sus primeras conferencias en 1911, deseaba la existencia de una literatura que pudiera expresar la vida de los motores y la aparición un nuevo hombre, un ser superior mecanizado, con partes reemplazables, ${ }^{9}$ el elogio de lo nuevo en los nadaístas es circunstancia corrosiva comunitaria con la historia.

Por otro lado, un poema de Gonzalo Arango que se acerca más a la crónica es aquél escrito después de la muerte de José William Aranguren, alias Capitán "Desquite". En esta

\footnotetext{
${ }^{8}$ Para referencias sobre la posición de la iglesia durante los años de "la violencia," véase: Daniel $\mathrm{H}$. Levine y Alexander W. Wilde, "The Catholic Church, 'Politics,' and Violence: The Colombian Case," The Review of Politics 39 (1977) 229-231.

${ }^{9}$ Marianne W. Martin, Futurist Art and Theory 1909-1915 (New York, NY: Hacker Art Books, 1978) 130.
} 
elegía Gonzalo Arango habla sobre "la violencia" con nombres propios, a través de la vida de un bandolero. Este hombre es "un poeta de la muerte," nos dice. No está lejos de ver una cierta hermandad del delincuente y asesino con el poeta, pues también él, Gonzalo Arango, poeta nadaísta, es un desadaptado social. Así el hombre es ... "un malhechor, un poeta de la muerte. Hacía del crimen una de las bellas artes. Mataba, se desquitaba, lo mataron. Se llamaba 'Desquite'." (Arango 46) Y Arango aprovecha la oportunidad para lanzar sus ataques directos contra el estado colombiano representativo de los partidos tradicionales, únicos responsables del genocidio nacional: "Lo mataron porque era un bandido y tenía que morir. Merecía morir sin duda, pero no más que los bandidos del poder." (Arango 46) A pesar de su pesimismo, en un momento del poema, baja su guardia de militancia nihilista y cree en algunos héroes. Nos dice que el bandido bien habría podido destacarse en la historia dentro de circunstancias diferentes. Su ponderación del héroe, sin embargo, se nos ofrece bajo un determinismo histórico y geográfico:

Con un ideal esa fuerza tenebrosa invertida en el crimen, se hubiera podido encarnar en un profeta, en un líder, al estilo Bolívar, Zapata o Fidel Castro." [...] No dudo que tal vez bajo otro suelo que no fuera el siniestro suelo de su patria, este bandolero hubiera podido ser un misionero o un auténtico revolucionario.

(Arango 46)

Con la anterior iconografia se asoma la posibilidad de que su pesimismo no sea total: "Siempre me ha parecido trágico el destino de ciertos hombres que equivocaron su camino, que perdieron su posibilidad de dirigir la historia." (Arango 46) De este modo, su poema (sin evitar el cliché), aunque nos parezca pesimista, conserva un grano de optimismo:

Se había hecho guerrillero siendo casi un niño. No para matar sino para que no lo mataran, para defender su derecho a vivir, que en su tiempo era la única causa humana que quedaba por defender en Colombia: jla vida!

(Arango 46)

Más adelante, en un planteamiento simpley en una ausencia de maniqueísmo, nos dice sobre la dualidad ética del bandido:

¿Era culpable? Sí. Porque era libre de elegir el asesinato y lo eligió.

Pero también era inocente en cuanto el asesinato lo eligió a él.

(Arango 46)

Por ello, Gonzalo Arango "profeta," como se creía, lanza su terrible presagio, cuya vigencia vemos en nuestros días:

¿No habrá manera de que Colombia en lugar de matar a sus hijos los haga dignos de vivir? Si Colombia no puede responder a esta pregunta, entonces profetizo una tragedia: "Desquite" resucitará, y la tierra volverá a ser regada de sangre, dolor y lágrimas.

(Arango 47)

Estos versos se constituyen en una crónica bañada de cierta actitud moral. A diferencia del "Poema revolucionario," donde se le vio hacer gala de un humor negro, aquí vemos los rasgos de alguna voluntad política suya, alimentándose en el reino de la posibilidad. Según 
Arango, el criminal "Desquite," resultado de esa cadena interminable de criminales y de crímenes que se desataron durante "la violencia," fue un hombre bueno, un producto de las circunstancias.

\section{JAIME JARAMILLO EsCobar (X-504)}

Este poeta nacido en Pueblorico, Antioquia en 1932, fue marcado por "la violencia" e hizo de ésta uno de sus temas angulares. (Romero, El nadaísmo colombiano 75). Sin embargo, la totalidad de su poesía presenta una dirección hacia la colectividad que expresa las diversas raíces étnicas de Colombia. (Cobo 232) Su escritura contiene, como bien lo dice el mismo Jaramillo: "Aglomeración amorfa de razas, de castas, de intereses, de egoísmos, montonera primitiva y errante, sin destino ..." (Cobo 232).

La poética de Jaramillo Escobar nos dice también de su infancia campesina, del servicio militar, de "la violencia" y de su registro en la mente del niño y adolescente para vertirla hecho hombre. "Los años cuarenta" es un poema que revela, con una sonrisa amarga, los albores de "la violencia" colombiana. Practica la taumaturgia de humor negro y su uso de máscaras le sirve a él para revelarnos la vergonzosa situación que la clase dominante esconde detrás de su mediocridad. Por eso parodia la voz de los políticos que le ofrecen a sus pueblos la historia de otras naciones, como panacea para ponerse al tanto de aquellos logros de los otros y como única posibilidad de salida del subdesarrollo:

Después de la guerra mundial también nosotros tuvimos nuestra
guerra, pues algo había que hacer,
Y nuestra cuota fue de trescientos mil muertos, pero ahí la hemos ido aumentando. (Romero, El nadaísmo colombiano 137)

Se respira en esta parodia la humildad y la resignación del campesino ante el destino. Construye la caricatura del sentimiento de superioridad y condescencia con que la clase dirigente mira siempre a la masa de labriegos que ellos mismos habian enviado a la muerte: "Al fin y al cabo, si no los matamos, de todos modos ellos se mueren." Las voces de la historia recogidas por el poeta hacen eco, y su parodia del campesino existe al lado del lenguaje de la clase dirigente. Jaramillo Escobar, ante la triste experiencia de su país, nos dará entonces lo único que puede ofrecernos: su visión irónica; aquella misma, según dice Lukács, que se da en el escritor en un mundo sin Dios, como su más alta libertad posible. ${ }^{10}$ Irreverencia a la patria, a las clases sociales y al lenguaje.

En "Los años cuarenta," a diferencia de los vates populares de "la violencia," el poeta no presenta su visión exaltada de los héroes. Su visión sobre Jorge Eliécer Gaitán carece del elemento elegíaco; en lugar de un discurso maniqueo alrededor de los héroes, existe una acusación apuntada hacia los partidos tradicionales:

Sí, terminaron mal los años cuarenta. La muerte de Gaitán, cuyos discursos vueltos a escuchar hoy suenan ridículos, fue sin embargo un acontecimiento que desbordó las previsiones

${ }^{10}$ George Lukács, Teoria de la novela (Buenos Aires: Ediciones Siglo Veintiuno, 1966) 89. 
de sus ejecutores y cuyas consecuencias no hemos calculado. ¡Tan difícil de calcular!

La historia de la época llamada Violenta se ha desfigurado y los partidos tratan de ocultarla, la minimizan, la disimulan, quisieran borrarla. (Romero, El nadaísmo colombiano 137)

Otro poema de Jaramillo Escobar donde hace una crónica del país durante la época de "la violencia," y donde ninguno de los partidos políticos escapa a su crítica es "Las hijas del muerto." Dicha relación de hechos en estos versos posee la misma parodia sarcástica presente en los otros. Su declaración es directa:

Porque aquél era el tiempo en que los colores se peleaban entre sí, el azul con el rojo, que están unidos en la bandera, se había ordenado separarlos. (Romero, El nadaísmo colombiano 138)

Se trata de una alusión clara a los campesinos de aquellas aldeas donde los símbolos cromáticos de los partidos políticos contenían una carga mortal: el rojo que los liberales asociaban con la bandera nacional y el azul que los conservadores asociaban, no solamente con los colores de la bandera, sino también con el color del cielo y con los colores de la Inmaculada Concepción. ${ }^{11}$ Ajeno a una posición partidista, nos refiere la historia patria a través del ejercicio hegemónico-agresivo de los partidos:
En la década de los años treinta, persecución religiosa bajo el color rojo. Grupos armados atacan a los fieles en los oficios religiosos. Disparan al altar, a la custodia expuesta. No se tome testimonio a los menores, dice el juez ...

(Romero, El nadaísmo colombiano 139)

Se deja ver en la visión del poeta una idea del carácter de guerra poco convencional que fue "la violencia," al decirnos sobre la naturaleza de la beligerancia alevosa y crímenes cometidos contra las familias que vivían en las zonas rurales:

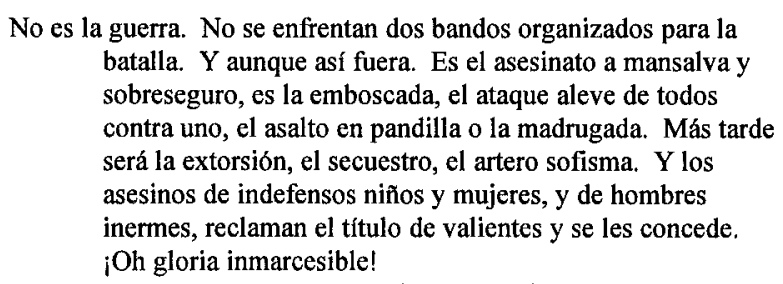

(Romero, El nadaismo colombiano 139)

${ }^{11}$ María Victoria Uribe A. Matar, rematar y contramatar (Bogotá: Centro de Investigaciones y Educación Popular, 1990) 95. Otras citas a este libro se darán con el apellido de la autora y el número de página. 
Además de presentarnos la crónica de los delitos cometidos por las facciones que se formaban en las veredas y los campos, cuyos asesinatos muchas veces fueron resultado de intrincadas venganzas no sólo partidistas sino también de conflictos personales, Jaramillo Escobar hace una acusación velada a los crímenes cometidos por la policía y el ejército; los "defensores" de la patria, el orden y las buenas costumbres. El primer verso "Oh, gloria inmarcesible" del Himno Nacional, le sirve para burlarse de los políticos del país, quienes se sirven de los valores patrios como la bandera y el himno nacional para engañar a las masas. El poeta denuncia la gran mentira que la clase dirigente instituye en los humildes en los pocos años de enseñanza en las escuelas primarias.

Luego nos ofrecerá una crónica más clara de la crueldad; la historia estalla en una suerte de antipoesía. La tanatomanía a la que se entregó el pueblo colombiano que apenas mencionaron los poetas populares, quienes escribieron poemas sobre "la violencia," es expresa en Jaramillo Escobar:

Y la venganza. Y el odio. No somos un pueblo carente de imaginación: si se le cortaba a alguien la cabeza, se le metían por el cuello las manos cortadas y se exhibía "el florero" Se abría la piel por el pecho, se extendía a los lados y se mostraba el murciélago... En el camino de Urrao se castraba a los hombres a golpes de mazo. El poema no admite más ejemplos. Acudid a las actas.

(Romero, El nadaísmo colombiano 140)

Se nos presenta una gama de atrocidades sobre los cadáveres; las macabras mortificaciones a que eran sometidos los cuerpos de las víctimas al final de las masacres, registradas en investigaciones sociológicas recientes:

Los brazos ocasionalmente se cortaban y se relocalizaban dentro del tronco, junto con las piernas, en el llamado corte de florero. Con este último el cuerpo sufría una profunda transformación que afectaba la cabeza, el tronco y las extremidades. (Uribe 175)

Porque se trataba no sólo de degradar a la víctima con maldiciones y malas palabras, sino que además de matarlas se las remataba y contramataba efectuando, con cuchillos, machetes y hachas, una serie de cortes sobre su cuerpo. Las aberrantes prácticas genocidas mencionadas por el poeta nadaísta coinciden con los informes sobre la decapitación, "el corte de franela," la desviceración, "el corte de florero" (Uribe 173-187) También, su denuncia de otros crímenes patológicos: "Arrojados desde aviones. Ametrallados. Bombardeados ...", coincide con los testimonios. El lanzar a las víctimas desde los aeroplanos fue una de las prácticas atroces de las fuerzas del estado, cuya imagen todavía vive en el recuerdo aterrorizado de los colombianos que vivieron durante esa época. ${ }^{12}$

\footnotetext{
12 Eduardo Fonseca Galán, Los combatientes del Llano 1949-1953 (Bogotá: Editorial Universidad INCCA, 1987) 72-74. En esta obra se halla consignada una carta firmada por el capitán Rafael Camargo Brand quien denuncia al ejército, su institución, por el asesinato sistemático de civiles, lanzándolos desde aviones "para economizar" munición.
} 


\section{Jota Mario ArbelÁeZ}

De este nadaísta (Cali 1940-) se ha dicho que es uno de los poetas colombianos con mayor talento natural y desparpajo innato (Darío Jaramillo 786). Aunque en un principio su poesía presenta algunas características de proselitismo político solidario con los campesinos afrentados por "la violencia," ésta es tocada por la vanguardia y evoluciona gracias al contacto con la Antología de la poesía surrealista de Aldo Pellegrini. (Romero, El nadaísmo colombiano 75) Con su imaginación desprevenida él es quien más se parece a los poetas vanguardistas. De un orden libertario único frente al sexo, algunos poemas suyos dejaron precedente en la poesía colombiana. Por otro lado, Jota Mario participa de la veta de humor negro propia de los otros nadaístas que hemos visto anteriormente (Darío Jaramillo 788-791). Con un tono autobiográfico, su poesía nos ofrece de manera burlesca y narcisista las experiencias de su niñez y adolescencia. Samuel Jaramillo complementa su semblanza literaria:

J. Mario dota a su poesía con un arsenal bastante peculiar: el humor corrosivo, la imagen dislocada, la irreverencia y el desenfado, que puestos al servicio de una inteligencia despierta y ambiciosa se convirtieron en armas poderosas de una crítica supremamente eficaz (o por lo menos muy urticante) de todo el contexto cultural procedente. Sin duda J. Mario, con menos arrogancia que otros en este sentido, ha sido mucho más incisivo y logrado en la práctica de un nuevo acercamiento a la cultura, que parte de una situación social tradicionalmente excluida de la sanción social en este terreno: la de los sectores populares urbanos (379).

Aspectos de "los sectores populares urbanos" y el clima familiar anecdótico se reproducen en "Carnal de la violencia," un poema sobre un padrino suyo:

La noche que se escriba el libro de la violencia en Colombia

Se hablará de Jorge Giraldo mi padrino

un hombre de esos que usaba revólver para no dejarse matar

Y sus gritos a su voz en puño para dar vivas al gran partido liberal y a Gabriel

Turbay

(Romero, El nadaismo colombiano 158)

En su viñeta familiar nos ofrece los recuerdos de la niñez y de la adolescencia donde uno de sus héroes favoritos es un hombre de aura vernácula que: "Tenía una carabina, un revólver y una peinilla." Su padrino, pues, es un personaje fácil de reconocer entre la población colombiana de origen campesino inmediato. En este ambiente hogareño, el poeta se halla rodeado y afectado por la vida política del país, pues su padrino también tenía: "una libreta ... (...) con consignas esas sí muy precisas y en tinta verde pensamientos / de Benjamín Herrera Carlos H. Pareja o el insurgente Jorge Eliécer (Romero, El nadaísmo colombiano 159). Este último nombre compuesto se refiere al líder liberal Jorge Eliécer Gaitán, quien se constituye en su puente de entrada a la crítica de la política del país: 
En la vida política de esta tierra ha corrido mucha sangre y mucho sancocho de y políticos ya del siglo de este poema /gallina no han terminado de hartarse de la una ni de lo otro

(Romero, El nadaísmo colombiano 159)

La nota folclórica se evidencia en el poema con toda su expresividad; la sangre vertida ha sido tan copiosa como la cantidad de discursos con que los políticos engañan en las aldeas a los humildes campesinos, los mismos que los agasajan con "sancocho de gallina," el plato típico nacional. Dentro de ese mismo contexto popular la historia y los eventos familiares hacen parte de la misma telaraña total de la vida del país.

\section{ARMANDo Romero}

Este poeta, nacido en Cali en 1944, fue uno de los miembros más jóvenes del movimiento quien, según Gonzalo Arango, junto a Jan Arb y Tadheo completaba la trinidad nadaísta novísima. ${ }^{13}$ Sus primeros poemas, como aquéllos de los demás poetas nadaístas, recogen la tradición del surrealismo y hacen brillar el absurdo de la vida citadina: "El lápiz labial que ayer se derretía sobre / la acera es hoy una mancha de sangre / sobre el asfalto".14

Sin embargo, la escritura de Romero evolucionó y en las características de su poesía se empezó a notar "un acercarse, un palpar, y un narrar," al decir de Alvaro Mutis. Tal condición se mantiene en su producción reciente, recogida en Las combinaciones debidas (1989) y A rienda suelta (1991). En estos últimos libros, que incluyen el poema de nuestro interés, se halla un tipo de creación que recoge los beneficios de la búsqueda de un lenguaje más americano; condición esta última que ya se daba como propuesta implícita de los nadaístas desde aquellos primeros textos incendiarios contra la tradición literaria nacional. La poesía de Romero, llena de los sonidos que se le pegaron desde la niñez, contiene también, como veremos, las vivencias de esa época temprana cargadas con aire de tragedia. Con limpieza de ropajes artificiales y muy de la tierra, con voces y juguetes de infancia, sus poemas son hechos de vida. ${ }^{15}$

Escrito bajo el tono de la evocación, "De los asesinos" presenta una visión decantada de "la violencia." Este poema, incluido en Las combinaciones debidas, y exento de la beligerancia y el espíritu inicial de sus primeros textos nadaístas recogidos en El poeta de vidrio, dice de un hecho atemperado en la memoria por los años. Nos toca, no con la fiebre de la inmediatez y la rabia, hecho que sí ocurre con los poemas de Gonzalo Arango y los de Jaime Jaramillo Escobar, en los cuales existen el sabor de crónica abierta e inmediata sobre "la violencia."

${ }^{13}$ Gonzalo Arango, De la nada al nadaismo (Bogotá: Ediciones Tercer Mundo, 1966) 23.

${ }^{14}$ Armando Romero, prol. Alvaro Mutis, Del aire a la mano (Bogotá:Instituto Colombiano de Cultura, 1983) 20. Las palabras de Alvaro Mutis que citaremos más adelante corresponden al prólogo de este libro.

${ }^{15}$ Miguel Ángel Zapata, "Armando Romero: escarbando el aire con las manos ..." Inti: Revista de literatura hispánica 26-27 (1988) 323. 
En el recuerdo "De los asesinos"16 se percibe la mirada del niño que no puede evitar sentir cierta fascinación por aquellos personajes siniestros, pues no ve en estos heraldos del mal la miseria que ellos traen: "Los asesinos olían a vaca y tierra aunque de común viajaban en jeeps o en automóviles negros a conciencia." No podemos evitar ver, con la visión de inocencia que nos hace sentir el poeta, en estos asesinos, su humanidad campesina con olor a terruño a pesar de que ahora, por razones de sus nuevos "trabajos," se movilicen en automotores. El niño simplemente evoca a esos campesinos que por cualquier razón se convertían en asesinos, pues con ellos tenía una comunidad de afinidades lugareñas que le hacía compartir con ellos: "un amor a los tangos que los hacía llorar de emoción cuando él se detenía al borde de sus cantinas a escuchar, perdido en la dulzura mortal de los bandoneones." (40) Dentro de esa hermandad, para la inocencia del niño, los asesinos "sonreían tiernos con sus dientes a caballo." Sus ojos rescatan, a pesar de la muerte que los otros encarnan, las sustancias de lo maravilloso para "su museo de imágenes" del universo, ${ }^{17}$ que el poeta escribe en la página. Pero aun así, su inocencia, desprovista de todo maniqueísmo, también discierne: "el brillo de sus ojos contrastaba eterno con el brillo de sus armas (40)" Porque "la violencia" estaba allí:

En la cantina de El Pijao nunca mataron a nadie, que yo sepa, aunque los asesinos bebían aguardiente y cantaban rancheras y tangos hasta la madrugada. Pero en la de Don Miguel, donde había un árbol hermoso y le regalaban una almendra de dulce cada vez que compraba algo para su madre, murió abaleado el pobre hombre que esa noche pedía agua, por favor, golpeando en todas las ventanas (41).

En una voz directa, más referencial, sobre ese clima de vida azarosa que forjó a la generación del poeta, la evocación "De los asesinos" viene de un bar, el lugar público popular, en los pueblos donde ocurria "la violencia. También, el recuerdo del niño (compartiendo los tangos, esa música popular que exalta el corazón y el machismo de los latinoamericanos), se halla mediatizado por una rabia cierta:

Del pasto de las fieras también comía su rabia cuando en el desfile de la soledad oía el murmullo de los asesinos. Si era en la noche arrastraban sus pies como si fueran chamizas puestas a barrer el patio; si era en la tarde sólo el sol violento desafiaba la ira de sus armas en la mesa de la cantina. Ganas daban de sacar la cauchera y ponerlos a raya, pero a doble llave su madre lo encerraba cuando, antecito de la cena, el toque de queda dictando la soledad se quedaba (42).

El círculo se ha cerrado. Primero el niño tiene una fascinación por sus "dientes a caballo" y ahora sabedor de la verdad macabra de sus fechorias de medianoche, siente la rabia por lo que su presencia significa. Quiere "ponerlos a raya" con la única arma de su universo infantil: "la cauchera."

\footnotetext{
${ }^{16}$ Armando Romero, Las combinaciones debidas (Buenos Aires: Ediciones Ultimo Reino, 1989) 40. Otras citas de este poema se darán con su número de página.

${ }^{17}$ Eduardo Espina, "Palabra y universo en la escritura de Armando Romero," Revista Iberoamericana 151 (1990) 537.
} 
Pero las experiencias de la niñez permanecen en la vida del hombre a pesar de las distancias geográficas. En otro momento del poema, la voz del adulto, nos dirá de las marcas que dejó "la violencia" en él: "De los sobrevivientes hablaba con H. aquella tarde en Cincinnati y recordamos (...) Nos quedamos en silencio cuando vino de improviso el aullido de los asesinos (44)." Ésta, aunque sea una irrupción mediatizada por el tiempo, parece salirle al paso con toda su furia como una pesadilla diurna. No hay sarcasmo ni humor negro en los versos de Romero, pero tampoco hay optimismo. Lo que queda a la salida del poema es el terror por la guerra entre hermanos. En el poema, que no es una voz de voluntad consolatoria (como tampoco lo han sido los poemas de los demas nadaístas), han quedado recogidos los dos momentos: el recuerdo en los ojos del niño y la presencia todavía viva de "la violencia" en las vidas de los colombianos. En el "museo de imágenes" (para reiterar la expresión de Eduardo Espina) de las páginas de Romero, "la violencia" también dejó su propia voluntad de exordio "de los asesinos."

No existe en la mayoría de los poemas de los nadaístas presentados aquí una respuesta esperanzada fundada en el arquetipo de la fecundación de la tierra por las víctimas, o en los héroes redentores de los poetas populares y de los poetas de Mito (poesía objeto de otro estudio), o la afirmación y la confianza, un tanto existencialista en la palabra, que alguna vez pidieron los poetas de Mito frente a los hechos de "la violencia." Los héroes, si éstos existen, según los nadaístas, son hombres de carne y hueso quienes producen discursos que "hoy suenan ridículos." Los versos de los nadaístas sostienen desde el pesimismo de humor negro en Gonzalo Arango y Jaime Jaramillo Escobar hasta las huellas de dicha violencia contenidas en el recuerdo sencillo de Jota Mario Arbeláez sobre su padrino, o, en el caso de Romero, a pesar de cierta mediatización temporal, la huella y presencia dejadas por "la violencia."

Es verdad que las armas de los nadaístas se constituyeron de estratagemas publicitarias (los dadaístas y los surrealistas también lo hicieron), insultos, $\mathrm{y}$, no pocas veces, cierto tremendismo poético; es cierto que su aparición coincidió con movimientos mundiales como la "Beat Generation" y la esperanza política que se vislumbró con la Revolución Cubana, pero su protesta no nació solamente de los anteriores, o ex-nihilo. "La violencia" hizo germinar en ellos el estilo y la actitud del desarraigado, el humor negro, la ironía y el absurdo que le inculcaron un cierto tono más libre a la poesía colombiana en su aletargado avance hacia la la modernidad. El estilo poético de los nadaístas, inclusive éste de sus textos sobre "la violencia," ejemplifica los cambios de la poesía colombiana después de los años de la guerra fratricida.

El movimiento de los nadaístas, en fin, una vanguardia a destiempo dentro de la poesía latinoamericana, mas no al interior de la poesía colombiana, se presentó como una de las puertas de salida ante la frustración. Ellos se lanzaron en contra de las clases dirigentes que habían enviado a los campesinos liberales y conservadores del país a que se mataran unos a otros, con la mentira de que existían diferencias profundas de principios filosóficos en sus partidos políticos. "La violencia" fue la sacudida al país de los colombianos que justificó su respuesta poética, ya fuera en rabiosos textos referenciales, en la evocación reflexiva, o en los golpes de humor negro asestados por Gonzalo Arango:

Alguna vez, en Cali, el poeta X-504 me dijo que el Nadaísmo era el segundo movimiento importante del país. Yo le pregunté que cuál era el primero y él me contestó que LA VIOLENCIA con 400.000 afiliados.

(Romero, El nadaismo colombiano 27) 